\title{
THE REDUCTION OF CHROMIUM AND CHEMICAL OXYGEN DEMAND OF BATIK EFFLUENT BY UNCALCINED AND CALCINED Mg/AI HYDROTALCITE ON VARIOUS pH TREATMENTS
}

\author{
L.I. Ardhayanti ${ }^{1,}$, I. Sahroni ${ }^{2}$, I. Darojat ${ }^{1}$ and A. Wigati ${ }^{1}$ \\ ${ }^{1}$ Department of Environmental Engineering, Faculty of Civil Engineering and Planning, \\ Universitas Islam Indonesia, Jl. Kaliurang Km14, Sleman, Yogyakarta, Indonesia \\ ${ }^{2}$ Department of Chemistry, Faculty of Mathematics and Science, Universitas Islam Indonesia, Jl. \\ Kaliurang Km14, Sleman, Yogyakarta, Indonesia \\ Corresponding Author: lutfia.isna@uii.ac.id
}

\begin{abstract}
The increasing Batik industry in Indonesia has an impact on wastewater production. The chemical compound in Batik wastewater such as dyes will contaminate the environment when it does not correctly treat, especially for a small-scale industry that usually does not have proper treatment before discharge to the environment. Adsorption is a simple and efficient method of reducing dyes. Hydrotalcite is an adsorbent material with rehydration properties. Hydrotalcite has been synthesized by the co-precipitation method. Rehydration properties improve Batik wastewater quality through $\mathrm{Cr}$ reduction and Chemical Oxygen Demand (COD) degradation with $\mathrm{pH}$ three as the optimum condition for adsorption. Ability to improve adsorption capacity after rehydration makes hydrotalcite possible as reusable material.
\end{abstract}

Keywords: Batik Wastewater, Adsorption, Hydrotalcite, Calcination, COD

RASĀYAN J. Chem., Vol. 14, No.4, 2021

\section{INTRODUCTION}

The population of the batik industry in Indonesia increased due to the announcement from UNESCO in 2009 that Batik was one of Indonesian cultural heritage. It has an impact on a higher volume of Batik wastewater discharge. Some compound has been mixed to get batik colors such as dyes (anionic or cationic dyes), resin, wax, and other chemicals in the dyeing process. ${ }^{1}$ Some industries, tiny scale industries, sometimes discharge their effluent directly to the environment without further treatment that will affect environmental conditions in negative ways, apart from its chemical compounds that sometimes are carcinogens. For example, the color of batik wastewater made an aesthetic problem and reduced the amount of oxygen dissolved in water. Some methods already offered to treat batik wastewater include membrane nanofiltration, ${ }^{1}$ electrocoagulation, ${ }^{2}$ adsorption, ${ }^{3}$ and photocatalytic degradation. ${ }^{4}$ Adsorption is one alternative treatment that is easily in preparation and low cost. Furthermore, specific material could be used several times with enhanced absorption capability after being used, like hydrotalcite.

Hydrotalcite is anionic clay that contains divalent and trivalent cations, and anion works as the counterion. Stawiński et al..$^{5}$ reported that $\mathrm{Mg} / \mathrm{Al}$ Hydrotalcite $(\mathrm{Mg} / \mathrm{Al} \mathrm{HT})$ after calcination enhanced its adsorption capability because of the reconstruction process. ${ }^{5} \mathrm{Mg} / \mathrm{Al}$ HT reported widely used as an adsorbent for dye, ${ }^{5,6,7}$ and metal. ${ }^{8,9}$ Even though some research has been conducted using Mg/Al HT as an adsorbent for dyes, few studies reported it used in sample effluent.

We previously reported the use of magnetite-hydrotalcite materials for dyes adsorption. ${ }^{10}$ Herein, we presented the influence of calcined and uncalcined $\mathrm{Mg} / \mathrm{Al} \mathrm{HT}$ as an adsorbent for batik wastewater treatment. Calcined and uncalcined $\mathrm{Mg} / \mathrm{Al} \mathrm{HT}$ performance was evaluated in terms of its function in Chromium $(\mathrm{Cr})$ reduction and COD degradation from batik wastewater under various $\mathrm{pH}$.

\section{EXPERIMENTAL}

All reagents were an analytical grade (Merck Co. Inc. Germany), and Batik wastewater was collected from a small-scale Batik industry in Sleman District, Yogyakarta, Indonesia. Batik wastewater is Rasayan J. Chem., 14(4), 2586-2590(2021)

http://dx.doi.org/10.31788/RJC.2021.1445620 
RASĀYAN J. Chem.

Vol. 14 | No. 4 |2586-2590| October- December | 2021

collected in a closed container with simple treatment (carbon active and coconut fiber placed at the bottom of the container as sorbent material). The sample was taken from the container using a glass bottle and stored in an icebox for further experiments.

\section{Mg/Al HT Synthesis}

$\mathrm{Mg} / \mathrm{Al} \mathrm{HT}$ was synthesis through the co-precipitation method. ${ }^{11}$ Dissolved $\mathrm{Mg}\left(\mathrm{NO}_{3}\right)_{2} \cdot 6 \mathrm{H}_{2} \mathrm{O}$ with $\mathrm{Al}\left(\mathrm{NO}_{3}\right)_{3} .9 \mathrm{H}_{2} \mathrm{O} ; 12.8 \mathrm{~g}$ and $9.4 \mathrm{~g}$ each in $100 \mathrm{~mL}$ DI water at the closed container. Add dropwise $\mathrm{NaOH}$ $1.65 \mathrm{M}$ to the solution until it reaches the base condition $(\mathrm{pH} 10)$. The prepared solution was then hydrothermally heated at $120{ }^{\circ} \mathrm{C}$ for 5 hours. Prepared $\mathrm{Mg} / \mathrm{Al} \mathrm{HT}$ was filtered, washed until it reached neutral $\mathrm{pH}(7.0-7.4)$, and left to dry at $100^{\circ} \mathrm{C}$. Then ground $\mathrm{Mg} / \mathrm{Al} \mathrm{HT}$ with mortar.

\section{Adsorption Experiments}

Pretreatment was used before the adsorption of Batik wastewater using the filtration process to remove impurities then diluted until reach required concentration.

The adsorption process was carried out in batch condition with $12.5 \mathrm{mg}$ of $\mathrm{Mg} / \mathrm{Al} \mathrm{HT}$ and $\mathrm{HCl}$ and $\mathrm{NaOH}$ were prepared each at $0.1 \mathrm{M} .12 .5 \mathrm{~mL}$ of Batik wastewater to adjust a solution. The mixture was then stirred for 2 hours, then filtered. The same procedure was applied to calcined $\mathrm{Mg} / \mathrm{Al}$ $\mathrm{HT}$. Optimum adsorption condition was getting with adjusted solution $\mathrm{pH}$ at 3, 5, 7 and 9. $\mathrm{Mg} / \mathrm{Al} \mathrm{HT}$ was calcined at $500{ }^{\circ} \mathrm{C}$ for 3 hours to get Calcined $\mathrm{Mg} / \mathrm{Al}$ Hydrotalcite. ${ }^{12}$

\section{Characterization}

The adsorbent materials were characterized using X-ray diffraction (XRD) by Shimadzu and Scanning Electron Microscope (SEM) by Phenom Thermo Scientific.

\section{Characterization of Materials}

\section{RESULTS AND DISCUSSION}

The diffractogram of synthesized materials through co-precipitation is shown in Fig.-1. From diffractogram, it has been shown that it has a similar peak with $\mathrm{Mg} / \mathrm{Al} \mathrm{HT}$ from Stawiński et al. ${ }^{5}$ with peak characteristic at $11^{\circ}(\mathrm{d} 003) ; 22^{\circ}(\mathrm{d} 006) ; 34.8^{\circ}(\mathrm{d} 012) ; 38-39^{\circ}(\mathrm{d} 015) ; 46^{\circ}(\mathrm{d} 018) ; 60^{\circ}(\mathrm{d} 110)$ and $61^{\circ}$ (d113). Calcined Mg/Al HT has a similar peak with uncalcined Mg/Al HT. This diffractogram reported that the calcination process in this research did not destroy its structure.

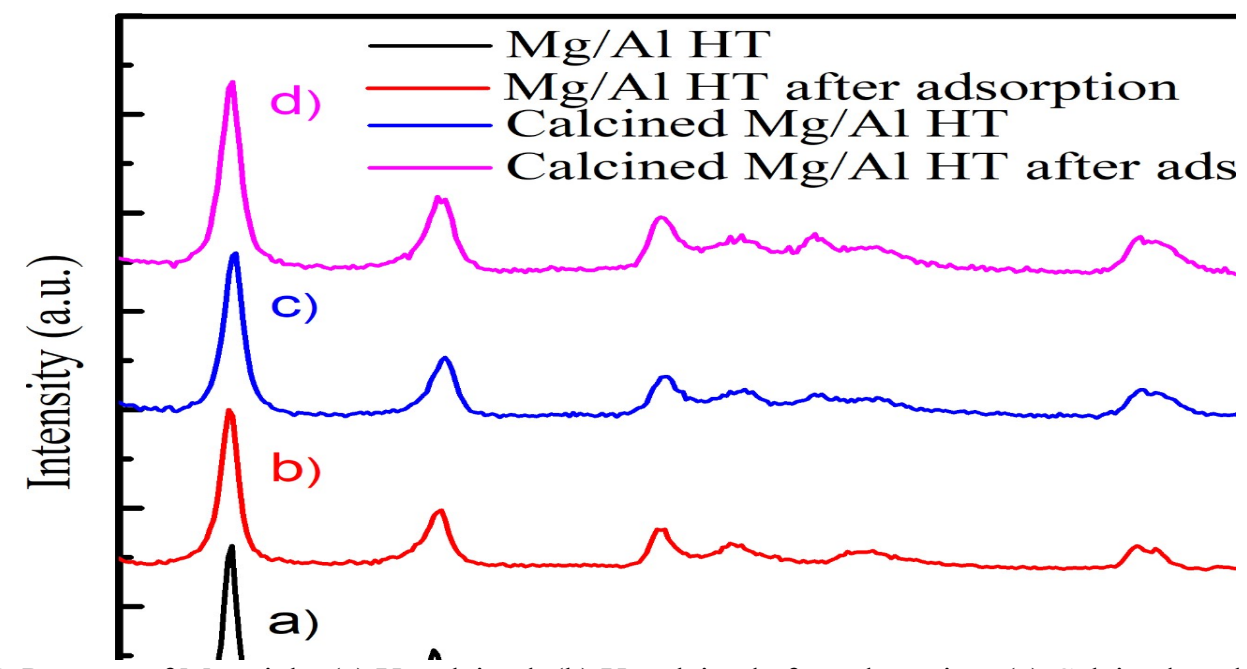

Fig.-1: XRD Patterns of Materials: (a) Uncalcined, (b) Uncalcined after adsorption, (c) Calcined, and (d) Calcined after adsorption

SEM was used to characterize morphologies of $\mathrm{Mg} / \mathrm{Al} \mathrm{HT}$ synthesize. From Fig.-2, morphologies of $\mathrm{Mg} / \mathrm{Al} \mathrm{HT}$ synthesized have nanosheets structure that similar to hydrotalcite reported by Huang et al. ${ }^{8}$ and Navajas et al. ${ }^{13}$ 

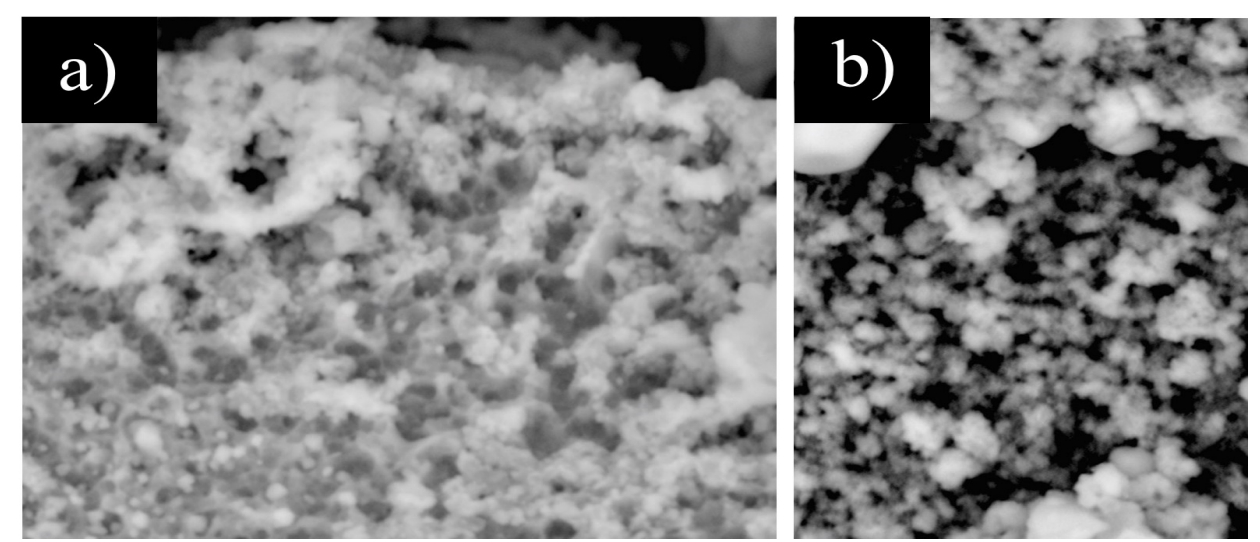

Fig.-2: SEM Image of Materials: (a) Uncalcined and (b) calcined

\section{Adsorption Experiments}

The composition of Batik wastewater would be affected by a chemical used in the processing step. Process production of Batik in the small-scale industry in Sleman categorizes as hand-written Batik (or 'batik tulis') that used pen-like tools called 'canthing' when applying wax. There are several steps used in Batik production. The early step is to draw molten wax using traditional tools (a pen-like tool called 'canthing') or a metallic stamp. The next step is the coloring process with dipping the cloth in the dye bath (sometimes they used salt to brighten up Batik's colour). The final process was rinsing, which eliminates wax using hot water (called 'pelorodan'). Based on this process, there are three main chemical compounds in Batik wastewater: wax (paraffin as dominant compound), dyes (vat and reactive dyes), and salt. Batik wastewater in small-scale industries is usually collected before further treatment in a closed container.

COD parameter used to represent various chemical compounds in Batik wastewaters. The color of Batik wastewater sample was yellowish black with $\mathrm{pH} 8$, COD $3500 \mathrm{mgL}^{-1}$ and $\mathrm{Cr}$ concentration at $17 \mathrm{mgL}^{-1}$. For the adsorption process, the sample was filtered to reduce the particulate and insoluble materials of Batik components; furthermore, it was diluted with DI water. Since $\mathrm{pH}$ conditions will affect the adsorption process, such as changing the surface charge of the adsorbent and adsorbate, ${ }^{14}$ adsorption processes in this research were conducted under different $\mathrm{pH}$ that describes acid, neutral and base conditions.

After the adsorption process, the COD parameter seems to reduce for both adsorbents, with calcined $\mathrm{Mg} / \mathrm{Al} \mathrm{HT}$ giving more significant degradation (Fig.-3). The higher capability of calcined $\mathrm{Mg} / \mathrm{Al} \mathrm{HT}$ in the adsorption process was predicted because the disappearance of some water and ionic compounds that interact at the surface and functional groups of materials after the calcination process made some space for another compound to interact with the material.

The optimum condition of COD degradation for both adsorbents happen at $\mathrm{pH} 3$, similar results with Birgani et al. ${ }^{15}$ The explanation is, at acid condition, the surface of $\mathrm{Mg} / \mathrm{Al} \mathrm{HT}$ contains hydroxyl groups in a protonated form. Since the surface charge of the adsorbent was affected by $\mathrm{pH}$ conditions, when increasing $\mathrm{pH}$ value, functional groups of the adsorbent will be deprotonated. Since the sample of Batik wastewater contains dominant organic materials (dyes), there are possible interactions between adsorbent and adsorbate through electrostatic interaction between hydroxyl groups of hydrotalcite layers and functional groups adsorbate. ${ }^{7,10,14,16}$ Since acid is the optimum condition of the adsorption process; anionic dyes are the dominant compound in the sample. ${ }^{14}$

Some references said that $\mathrm{Mg} / \mathrm{Al} \mathrm{HT}$ would reconstruct its structure after destruction after calcination, affecting its capability on adsorption. ${ }^{7}$ While, Fig.-1, the calcination process does not seem to destroy the $\mathrm{Mg} / \mathrm{Al} \mathrm{HT}$ structure, it still impacts a higher adsorption process than uncalcined hydrotalcite. It is proven from the diffractogram that the intensity of peaks is increased after the adsorption process.

Similar to an optimum condition for COD degradation, the optimum condition for $\mathrm{Cr}$ reduction of both adsorbents is at $\mathrm{pH} 3$ (Fig.-4). Possibility explanation from this process was an interaction between functional groups adsorbent, and $\mathrm{Cr}$ speciation was electrostatic interaction., ${ }^{9,20,21,22} \mathrm{Cr}$ speciation was dominantly affected by $\mathrm{Cr}(\mathrm{VI})$ that was anionic. At acidic conditions, functional groups of adsorbents are 2588 
RASĀYAN J. Chem.

Vol. 14 | No. 4 |2586-2590| October- December | 2021

a protonated form, then $\mathrm{Cr}$ speciation happens at anion condition. The adsorption of $\mathrm{Cr}$ speciation decreases with increasing $\mathrm{pH}$. While, at base condition, the adsorption process for $\mathrm{Cr}$ seems to increase because usually, metals are in precipitated form. An indication that $\mathrm{Cr}$ was precipitate is the addition of total dissolved solids at the base condition in this research: approximately $1400 \mathrm{mgL}^{-1}$.

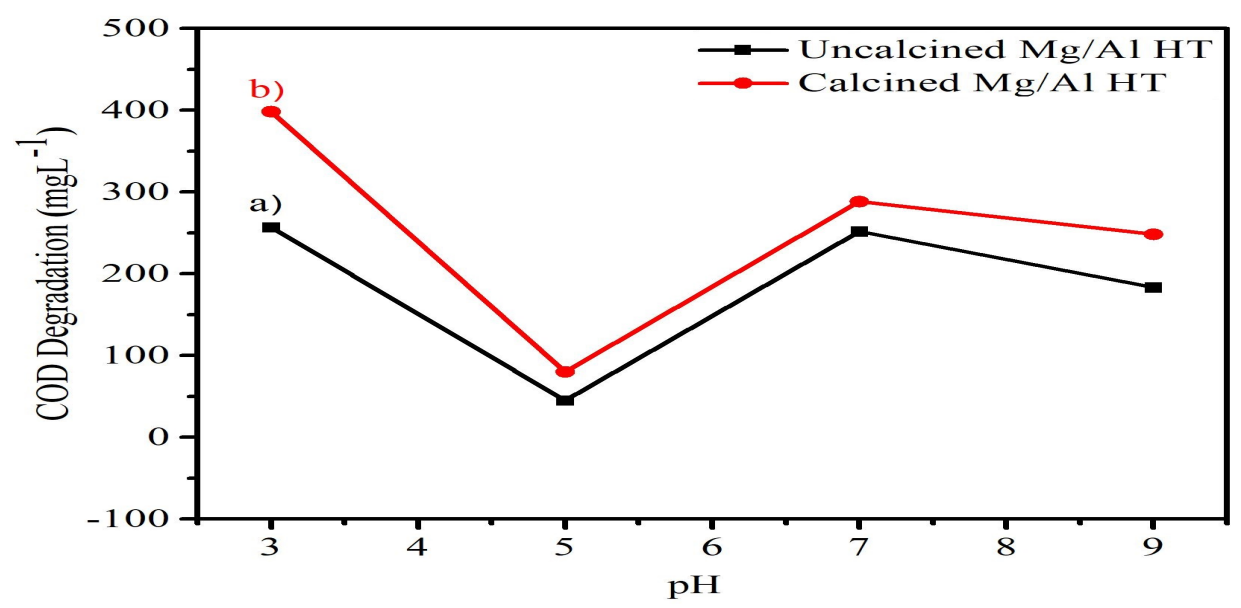

Fig.-3: COD Degradation ( $\left.\mathrm{mgL}^{-1}\right)$ of (a) $\mathrm{Mg} / \mathrm{Al} \mathrm{HT}$ and (b) Calcined $\mathrm{Mg} / \mathrm{Al} \mathrm{HT}$

Even though the COD reduction showed a lower value than biosorbent materials by Patel and Vashi ${ }^{17}$ (Table-1), it can be used several times. ${ }^{10}$ Based on government regulation in Indonesia for textile effluent, COD and Cr parameters have limitation values at $150 \mathrm{mgL}^{-1}$ and $1 \mathrm{mgL}^{-1}$. The result of this research is still above the permissible limit by the government. Then, for direct application, this method needs to enhance parameter experiment such as temperature and contact time or additional method for complement process so it could fulfill the requirement.

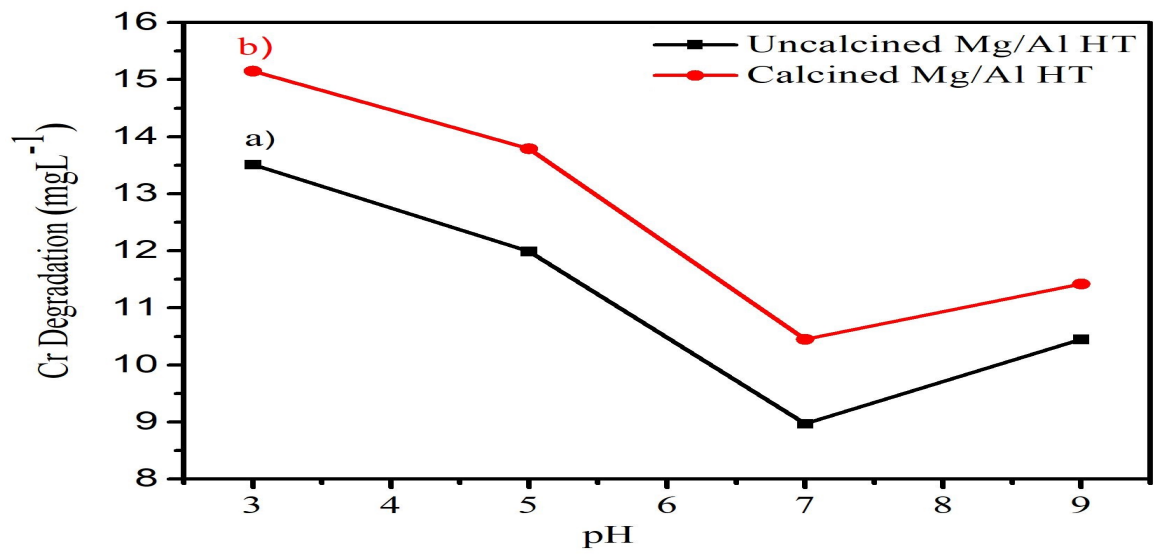

Fig.-4: Cr Reduction of (a) Uncalcined and (b) Calcined Mg/Al HT Material

Table-1: Comparison of COD Degradation from Textile Wastewater

\begin{tabular}{c|c|c}
\hline Adsorbent & COD degradation & References \\
\hline Activated of natural materials & $1400-1600 \mathrm{mgL}^{-1}$ & Patel and Vashi ${ }^{17}$ \\
\hline $\begin{array}{c}\text { Plastic Sheet coated by } \mathrm{TiO}_{2} \\
\text { nanoparticles }\end{array}$ & $97 \mathrm{mgL}^{-1}$ & Sutisna et al. $^{18}$ \\
\hline Bioequalization-electrocatalytic & $178 \mathrm{mgL}^{-1}$ & Mukimin et al. $^{19}$ \\
\hline Calcined and Uncalcined Mg/Al HT & $250-400 \mathrm{mgL}^{-1}$ & this research result \\
\hline
\end{tabular}

\section{CONCLUSION}

$\mathrm{Mg} / \mathrm{Al} \mathrm{HT}$ can enhance batik wastewater quality by reducing COD and $\mathrm{Cr}$; each was $256.7 \mathrm{mgL}^{-1}$ and $13.5 \mathrm{mgL}^{-1}$. Calcined material has better adsorption capability than uncalcined with almost double the amount of COD that can be reduced (the adsorption capacity was 398.3 and $256.7 \mathrm{mgL}^{-1}$ ). 
RASĀYAN J. Chem.

Vol. 14 | No. 4 |2586-2590| October- December | 2021

\section{ACKNOWLEDGMENT}

Authors would like to express appreciation for the support from Direktorat Penelitian dan Pengabdian Masyarakat (DPPM) Universitas Islam Indonesia for funding this research.

\section{REFERENCES}

1. H. R. Rashidi, N. M. N. Sulaiman, N. A. Hashim, Procedia Engineering, 44, 2010(2012), https://doi.org/10.1016/j.proeng.2012.09.025

2. Riyanto, E. Puspitasari, IOP Conference Series: Materials Science and Engineering, 299, 1(2018), https://doi.org/10.1088/1757-899X/299/1/012081

3. L. Xiao, W. Ma, M. Han, Z. Cheng, Journal of Hazardous Materials, 186(1), 690(2011), http://doi.org/10.1016/j.jhazmat.2010.11.052

4. W. F. Khalik, L. N. Ho, S. A. Ong, Y. S. Wong, N. A, Yusoff, F. Ridwan, Sains Malaysiana, 44(4), 607(2015), http://doi.org/10.17576/jsm-2015-4404-16

5. W. Stawiński, A. Węgrzyn, O. Freitas, L. Chmielarz, S. Figueiredo, Microporous and Mesoporous Materials, 250, 72(2017), https://doi.org/10.1016/j.micromeso.2017.05.017

6. B. Li, Y. Zhang, X. Zhou, Z. Liu, Q. Liu, X. Li, Journal of Alloys and Compounds, 673, 265(2016), https://doi.org/10.1016/j.jallcom.2016.02.048

7. Y. Lin, Q. Fang, B. Chen, Chemical Engineering Journal, 237, 38(2014), https://doi.org/10.1016/j.cej.2013.10.004

8. P. P. Huang, C. Y. Cao, F. Wei, Y. Bin Sun, W. G. Song, RSC Advances, 5(14), 10412(2015), https://doi.org/10.1039/c4ra15160g

9. E. Rodrigues, O. Almeida, H. Brasil, D. Moraes, M. A. L. dos Reis, Applied Clay Science, 172, 57(2019), https://doi.org/10.1016/j.clay.2019.02.018

10. L. I. Ardhayanti, S. Juari, Procedia Engineering, 148, 1380(2016), https://doi.org/10.1016/j.proeng.2016.06.609

11. Q. Chang, L. Zhu, Z. Luo, M. Lei, S. Zhang, H. Tang, Ultrasonics Sonochemistry, 18(2), 553(2011), https://doi.org/10.1016/j.ultsonch.2010.10.001

12. P. Cai, H. Zheng, C. Wang, H. Ma, J. Hu, Y. Pu, P. Liang, Journal of Hazardous Materials, 213-214, 100(2012), https://doi.org/10.1016/j.jhazmat.2012.01.069

13. A. Navajas, I. Campo, A. Moral, J. Echave, O. Sanz, M. Montes, J. A. Odriozola, G. Arzamendi, L. M. Gandía, Fuel, 211, 173(2018), https://doi.org/10.1016/j.fuel.2017.09.061

14. R. Elmoubarki, F. Z. Mahjoubi, A. Elhalil, H. Tounsadi, M. Abdennouri, M. Sadiq, S. Qourzal, A. Zouhri, N. Barka, Journal of Materials Research and Technology, 6(3), 271(2017), https://doi.org/10.1016/j.jmrt.2016.09.007

15. P. M. Birgani, N. Ranjbar, R. C. Abdullah, K. T. Wong, G. Lee, S. Ibrahim, C. Park, Y. Yoon, M. Jang, Journal of Environmental Management, 184, 229(2016), https://doi.org/10.1016/j.jenvman.2016.09.066

16. M. M. Hassan, C. M. Carr, Chemosphere, 209, 201(2018), https://doi.org/10.1016/j.chemosphere.2018.06.043

17. H. Patel, R. T. Vashi, 2015, in Characterization and Treatment of Textile Wastewater, Batch Adsorption Treatment of Textile Wastewater, Elsevier Inc., Oxford, pp. 111-125.

18. S. Sutisna, E. Wibowo, M. Rokhmat, D. Y. Rahman, R. Murniati, Khairurrijal, M. Abdullah, Procedia Engineering, 170, 78(2017), https://doi.org/10.1016/j.proeng.2017.03.015

19. A. Mukimin, H. Vistanty, N. Zen, A. Purwanto, K. A. Wicaksono, Journal of Water Process Engineering, 21, 77(2018), https://doi.org/10.1016/j.jwpe.2017.12.004

20. Y. H. Rao, K. Ravindhranath, Rasayan Journal of Chemistry, 10(4), 1104(2017), http://doi.org/10.7324/RJC.2017.1041829

21. T. Taher, R. Mohadi, A. Lesbani, Rasayan Journal of Chemistry, 11(3), 1244(2018), http://doi.org/10.31788/RJC.2018.1133065

22. R. E. K. Billah, Y. Elyamani, Y. Rakhila, M. Agunaou, A. Soufiane, Rasayan Journal of Chemistry, 12(1), 347(2019), http://doi.org/10.31788/RJC.2019.1215078

[RJC-5620/2020]

2590

REDUCTION OF CHROMIUM AND COD OF BATIK EFFLUENT

L.I. Ardhayanti et al. 